\title{
2019 年香港日本語学習者背景調査 \\ The 2019 Survey of Japanese Language Learners in Hong Kong \\ 斎藤誠、梁安玉、許淑君、李澤森、李夢娟 香港日本語教育研究会
}

\section{要旨}

本調査では、日本語能力試験（以下、JLPT）受験者を対象に香港の日本語独学者 の学習環境、意識、学習方法、効果実感度などについて調査した。その結果、独学者 は自身のペースで学習できることに利点を感じており、印刷物教材やウェブコン テンツ、映画・ドラマ・アニメなど視聴覚リソースの視聴など複数の学習方法を併用 しており、それぞれに一定の効果を感じているが、初級学習者が対象である本調査で は、友人やSNS での交流について相対的に評価が低かった。独学の課題としては 自身の日本語能力を確認寸る機会がないこと、学習方法がわからないという意見が多 かった。クラス学習者との比較では、独学者の言語能力向上の実感度が相対的に低い ことがわかった。

\section{キーワード :}

日本語独学者 学習方法 学習効果 学習計画 


\section{9 年香港日本語学習者背景調査}

\section{斎藤誠、梁安玉、許淑君、李澤森、李夢娟 \\ 香港日本語教育研究会}

\section{1.はじめに}

これまでの「香港日本語学習者背景調查」（木山他 2011、宇田川他 2014、山下他 2018、斎藤他 2019）で、香港の日本語学習者の学習目的は「日本語でコミュニケー ションができるようになりたい」「日本に旅行に行くため」「日本語自体への興味」 「ドラマや映画・マンガなどを日本語で理解したい」が多いことが明らかになっている。

香港の日本語教育機関で学習寸る人数は 2015 年の調査で 22,613 人（国際交流基金 2015）であるが、これはあくまで日本語教育機関で学ぶ人数であり、機関に通わない 日本語学習者は含まれていない。国際交流基金・電通（2016）は推計で、香港の日本 語学習経験者の割合は人口の 9.7\%で、計算上 35 52 万人（2014 年の人口統計） という数字を示し、独学者の潜在性を示唆している。香港日本語教育研究会（以下、 研究会) が香港・マカオで実施団体として年 2 回運営している日本語能力試験 (以下、 JLPT）には、日本語教育機関での学習者（以下、機関学習者）のみならず、独学者 も多く受験に来る。研究会が毎年発行する『日本学刊』にて毎年公開している「香港・ マカオ日本語能力試験実施報告」によると、香港・マカオ会場への日本語能力試験 申込書類にある質問「日本語学習の場」への回答について、2011 年以降のデーダを 見ると、図 1 の通り「日本語教育機関で日本語を学んでいない」と回答した人が年々 増加し、2017 年 12 月に 4 割を超え、2019 年 7 月で $41.1 \% 、 12$ 月で $42.5 \%$ とって いる。なお、この統計をレベル別に見ると、「教育機関で学んでいない」人の割合は N5 で 2 割強、レベルが上がるにつれてその割合も上がり、N1 は 6 割を超えている。 このレベル別の比率は 2011 年から 19 年まで同じ傾向となっている2。

日本語教育機関に通わない日本語使用者の中には、独学者だけでなく、個人教授を 受けている人、通信教育受講者、学習をしていない人など様々な人がいると考えられ るが、本稿において独学者とは「調査段階で日本語教育機関（民間語学学校を含む） に通ったり通信教育、個人授業などを受けておらず、自身で学習している人」のこと である。

スマートホンの所有が当たり前となり、インターネットがインフラとして整備され、 手軽に外国語学習が可能になった昨今の香港の社会環境の中で、独学者はどのような 意識で日本語を学習し、どんな点に手応えを感じているのだろうか。日本語学習機関

香港で JLPT が年 2 回とも全レベル受験可能になった 2011 年以降のデータを集計した。

劉（2012、2013、2014、2015、2016、2017、2018、2019）、許（2020）による。 
の授業、コースデザインにフィードバックできる点はないだろうか。本論では、独学 にどんな効果、利点、課題があるのかを探るべく、香港の日本語独習者に調查した 結果を報告する。

\section{図 1 日本語学習の場 (推移) ${ }^{3}$}

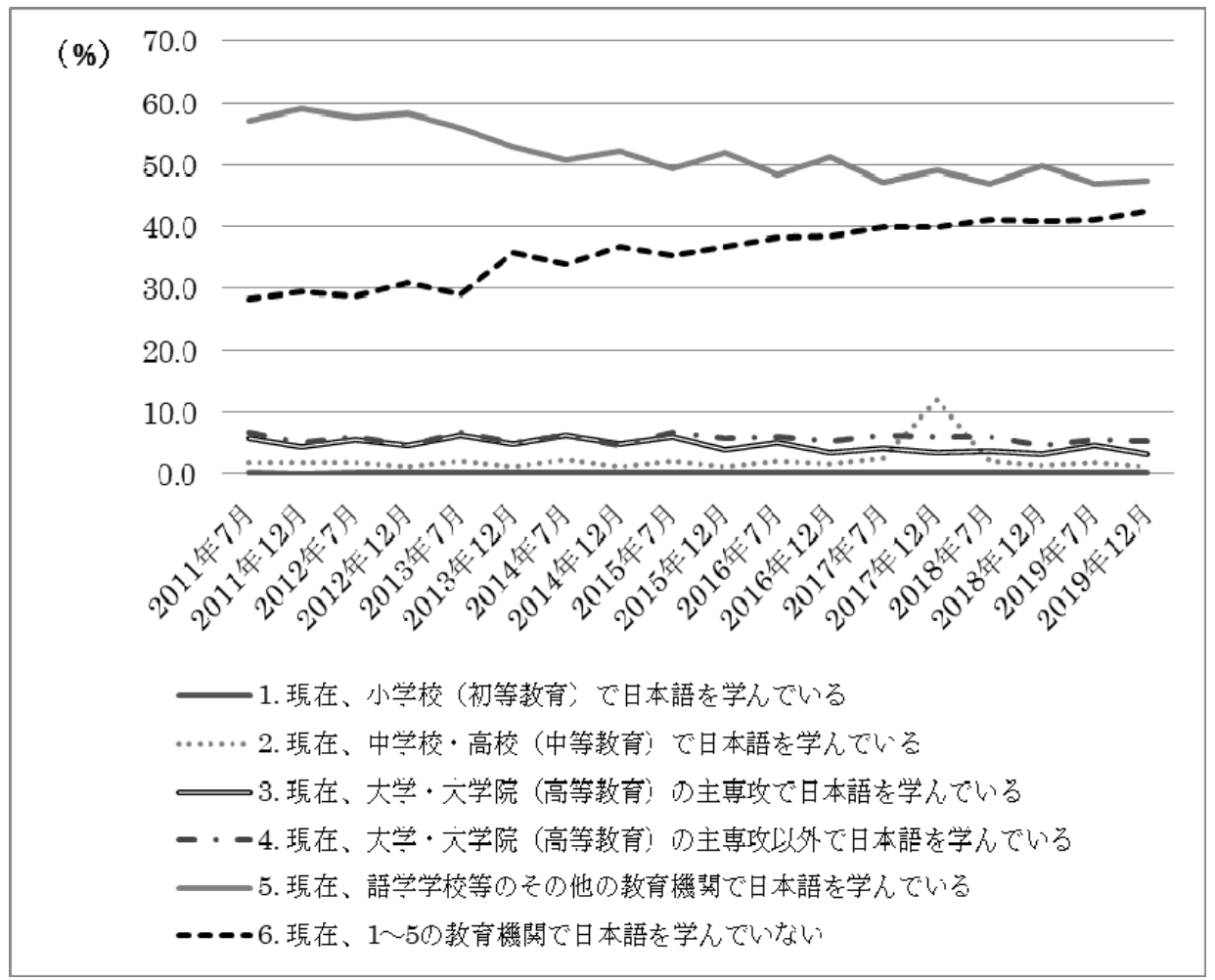

\section{2. 先行研究、調查の目的}

香港における日本語学習者で、独学者を対象にした調査では、国際交流基金・電通 （2016）があり、1000 件のサンプル調査より人口に占める割合の推定值を算出して いる。それによると、日本語の学習経験者は人口の $38.9 \%$ 、現在学習中の割合は $9.7 \%$ 、 また学習経験者のうち、独学の割合を 48.2\%、機関での学習経験なしの独学者の割合 を29.4\%としている。

香港の独学者への質的調査では、瀬尾・山口（2014）がある。独学（インフォー マル・ラーニング）で N1 に合格した人へのインタビューから、日本語を文化資本 として習得することの難しさ、香港で日常的に触れる日本の大衆文化や商品の影響、 自分の関心のある分野から自分で日本語学習を進めている実態を明らかにし、多様な 学習背景を持つ学習者像の一端を示している。

3 劉（2012、2013、2014、2015、2016、2017、2018、2019）、許（2020）より作成。 
量的調査では、宇田川他（2016）が 2013 年の調查で、独学者が独学をしている 理由、学習方法について質問し、さらに質的調査として 5 人 ${ }^{4}$ のインタビューから、 独学をしている理由が「仕事や学業の忙しさ」「金銭的理由」が多く、「独学に固執 しているわけではない」という流動的な学びの方法の実態を明らかにし、子どもの ころから日本語に接していたり、趣味として日本語を学習する姿を映し、「生涯学習 できる学習という視点（宇田川他 2016 : 152）」を重視すべきだと述べている。この 調査では、独学者の学習方法などが明らかにしているが、学習効果の実感度など、 学習の実態は詳細には調査されていない。

本調査では、以上の先行研究を踏まえ、初級日本語独学者への量的調査を通して「独 学の利点、効果がどんな点にあり、また各学習方法にどのくらい効果があると感じて いるのか、また課題に感じているのか」を知り、「香港の日本語教育機関に通う学習 者と独学者との間で、実感している学習効果などにどのような違いがあるのか」を調 査したいと考えた。また、独学とクラス学習は別建てで存在しているものではなく、 学習者は状況に応じて流動的に移動するので、独学を経てクラス授業に入る学習者も 数多いと思われる。このような日本語学習者の学習歴や日本語学習に対する意識を 把握することは、日本語教育関係者にとって参考になると考える。

\section{3. 調查方法 - 調查協力者について \\ 3.1 調查方法}

対象者： 2019 年 6 月、11月に研究会が実施した JLPT 応募者（N4、N5）を対 象とした学習者背景調査に協力をいただいた方。

調査方法 : 調查協力者に質問用紙を配布し、記入したものを研究会担当者が回 収した。回答形式は主に選択式（「その他」欄は自由記述形式）。 質問用紙は中国語（繁体字）で作成したものを配布した。

集計方法：表計算ソフトにデータ入力した。なお、中国語で書かれた自由記述 箇所は筆者 ${ }^{5}$ が日本語に訳した。

\section{2 調查協力者の基本情報}

調查協力者は 6 月 378 人（N4 233 人、N5 145 人）、11月 282 人（N4 173人、N5 109 人）の計 660 人である。年齢別の内訳は表 1 の通りである。今回の調査協力者は 18 歳〜30 歳代が多くを占めている。表 2 の職業を見ると、社会人が 6 割以上を占め、 高等教育機関の学生が 3 割近くとなっている。独学者のみを抽出すると、N4 は大学 生、N5 は社会人の割合が高くなっている。

4 協力者は JLPT で N2 以上の応募者から選定

5 李夢娟が担当した。 
表 3 日本語学習歴では、N4 協力者は半年〜 3 年未満、N5 協力者は 2 年未満が多数 を占めている。独学者のみを見ると、 1 年未満の割合が高くなり、学習歴の短い人が 多いことがわかる。

表 1 レベル別年齢

\begin{tabular}{|c|c|c|c|c|c|c|c|c|c|c|}
\hline & \multicolumn{5}{|c|}{ N4 } & \multicolumn{5}{|c|}{ N5 } \\
\hline & 6 月 & 11 月 & 計 & $\%$ & $\begin{array}{c}\text { 独学者 } \\
(\%)\end{array}$ & 6 月 & 11 月 & 計 & $\%$ & $\begin{array}{c}\text { 独学者 } \\
(\%)\end{array}$ \\
\hline a.11 歳以下 & 0 & .3 & 3 & 0.7 & 0.0 & 3 & 0 & 3 & 1.2 & 0.0 \\
\hline b.12〜17 歳 & 10 & 10 & 20 & 4.9 & 3.5 & 8 & 5 & 13 & 5.1 & 3.4 \\
\hline c. $18 \sim 22$ 歳 & 40 & 26 & 66 & 16.3 & 24.3 & 22 & 22 & 44 & 17.3 & 13.8 \\
\hline d.23〜29 歳 & 95 & 69 & 164 & 40.4 & 46.5 & 59 & 40 & 99 & 39.0 & 43.1 \\
\hline e.30〜39 歳 & 63 & 39 & 102 & 25.1 & 14.6 & 31 & 17 & 48 & 18.9 & 15.5 \\
\hline f.40 49 歳 & 13 & 17 & 30 & 7.4 & 5.6 & 17 & 14 & 31 & 12.2 & 17.2 \\
\hline g.50〜59 歳 & 11 & 9 & 20 & 4.9 & 4.9 & 4 & 11 & 15 & 5.9 & 6.9 \\
\hline h.60〜69 歳 & 1 & 0 & 1 & 0.7 & 0.7 & 1 & 0 & 1 & 0.4 & 0.0 \\
\hline i.70 歳以上 & 0 & 0 & 0 & 0.0 & 0.0 & 0 & 0 & 0 & 0.0 & 0.0 \\
\hline 計 & 233 & 173 & 406 & & & 145 & 109 & 254 & & \\
\hline 総計 & & & & & & & & & & 660 \\
\hline
\end{tabular}

表 2 レベル別職業

\begin{tabular}{|c|c|c|c|c|c|c|c|c|c|}
\hline & \multicolumn{3}{|c|}{ N4 } & \multicolumn{3}{|c|}{ N5 } & \multicolumn{3}{|c|}{ 計 } \\
\hline & 人 & $\%$ & $\begin{array}{c}\text { 独学者 } \\
(\%)\end{array}$ & 人 & $\%$ & $\begin{array}{c}\text { 独学者 } \\
(\%)\end{array}$ & 人 & $\%$ & $\begin{array}{c}\text { 独学者 } \\
(\%)\end{array}$ \\
\hline a. 小学生 & 2 & 0.5 & 0.0 & 4 & 1.6 & 0.0 & 6 & 0.9 & 0.0 \\
\hline b. 中・高生 & 23 & 5.7 & 4.2 & 15 & 5.9 & 5.2 & 38 & 5.8 & 4.5 \\
\hline c. 短大 (副学士 $\mathrm{AD} \cdot \mathrm{HD})$ & 18 & 4.4 & 6.9 & 12 & 4.7 & 0.0 & 30 & 4.6 & 5.0 \\
\hline d. 大学生 & 79 & 19.5 & 28.5 & 45 & 17.7 & 17.2 & 124 & 19.1 & 25.2 \\
\hline e. 大学院生 (MA, PhD) & 20 & 4.9 & 4.2 & 15 & 5.9 & 5.2 & 35 & 5.4 & 4.5 \\
\hline f. 就労、会社員 & 252 & 62.1 & 54.2 & 151 & 59.4 & 70.7 & 403 & 62.0 & 58.9 \\
\hline g. 年金生活者 & 8 & 2.0 & 2.1 & 7 & 2.8 & 1.7 & 15 & 2.3 & 2.0 \\
\hline h. その他 & 4 & 1.0 & 0.0 & 5 & 2.0 & 0.0 & 9 & 1.4 & 0.0 \\
\hline
\end{tabular}


表 3 レベル別日本語学習歴

\begin{tabular}{|c|c|c|c|c|c|c|c|c|c|}
\hline & \multicolumn{3}{|c|}{ N4 } & \multicolumn{3}{|c|}{ N5 } & \multicolumn{3}{|c|}{ 計 } \\
\hline & 人 & $\%$ & $\begin{array}{c}\text { 独学者 } \\
(\%)\end{array}$ & 人 & $\%$ & $\begin{array}{c}\text { 独学者 } \\
(\%)\end{array}$ & 人 & $\%$ & $\begin{array}{c}\text { 独学者 } \\
(\%)\end{array}$ \\
\hline a. 半年未満 & 42 & 10.3 & 21.5 & 42 & 16.5 & 34.5 & 84 & 12.9 & 25.2 \\
\hline b.半年 1 年未満 & 63 & 15.5 & 24.3 & 71 & 28.0 & 29.3 & 134 & 20.6 & 28.2 \\
\hline c. 1 年 $\sim 2$ 年未満 & 154 & 37.9 & 33.3 & 110 & 43.3 & 27.6 & 264 & 40.6 & 31.7 \\
\hline d. 2 年 $\sim 3$ 年未満 & 98 & 24.1 & 9.7 & 21 & 8.3 & 3.4 & 119 & 18.3 & 7.9 \\
\hline e. 3 年 $\sim 4$ 年未満 & 28 & 6.9 & 4.2 & 3 & 1.2 & 1.7 & 31 & 4.8 & 3.5 \\
\hline f. 3 年 $\sim 4$ 年未満 & 6 & 1.5 & 1.4 & 4 & 1.6 & 3.4 & 10 & 1.5 & 2.0 \\
\hline g. 5 年以上 & 14 & 3.4 & 5.6 & 3 & 1.2 & 0.0 & 17 & 2.6 & 4.0 \\
\hline h. 不明 & 1 & 0.2 & 0.0 & $\mathbf{0}$ & 0.0 & 0.0 & 1 & 0.2 & 0.0 \\
\hline
\end{tabular}

表 4 学習環境（教育機関等）については、複数の教育機関に通つている人、機関と 個人授業など、複数の場で学ぶ人もいると想定されるため、複数回答可とした。割合 では、民間日本語学校で学習している人と、独学者の割合が高い。国際交流基金・電 通（2016）では、独学のみで機関で学習していない学習者の割合が $29.4 \%$ とるが、 斎藤他（2019）での調査では「独学者」は22.7\%、本調査では $31.7 \%$ となっている。

表 4 レベル別学習環境（教育機関等）

\begin{tabular}{|c|c|c|c|c|c|c|}
\hline & \multicolumn{2}{|c|}{ N4 } & \multicolumn{2}{|c|}{ N5 } & \multicolumn{2}{|c|}{ 計 } \\
\hline & 人 & $\%$ & 人 & $\%$ & 人 & $\%$ \\
\hline a.小学校 & $\mathbf{0}$ & 0.0 & 2 & 0.8 & 2 & 0.3 \\
\hline b.中・高校 & 3 & 0.7 & 1 & 0.4 & 4 & 0.6 \\
\hline c.副学士（AD/HD） & 4 & 1.0 & 1 & 0.4 & 5 & 0.8 \\
\hline d. 大学. 大学院の主/副専攻 & 7 & 1.7 & $\mathbf{0}$ & 0.0 & 7 & 1.1 \\
\hline e.大学の選択科目 & 8 & 2.0 & 1 & 0.4 & 9 & 1.4 \\
\hline f. 大学付属機関 - 社会人講座 & 44 & 10.8 & 27 & 10.6 & 71 & 10.9 \\
\hline g.語学学校（民間） & 177 & 43.6 & 133 & 52.4 & 310 & 47.7 \\
\hline h. 独学 & 147 & 36.2 & 59 & 23.2 & 206 & 31.7 \\
\hline i. 個人教授 & 32 & 7.9 & 22 & 8.7 & 54 & 8.3 \\
\hline j.今は勉強していない & 17 & 4.2 & 16 & 6.3 & 33 & 5.1 \\
\hline k. その他 & $\mathbf{0}$ & 0.0 & $\mathbf{0}$ & 0.0 & $\mathbf{0}$ & 0.0 \\
\hline
\end{tabular}

※複数回答可 


\section{9 年香港日本語学習者背景調査}

\section{4. 調査内容 - 結果}

本調査の協力者 660 人のうち、独学者 6 は 202 人で、全体の $30.6 \%$ ある。 $\mathrm{N} 4$ は 406

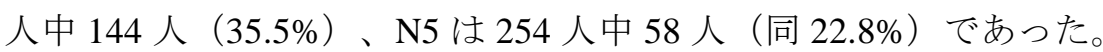

\section{1 独学をする場所}

表 5 の通りほとんどの人が「自宅」で学習しており、また公共交通機関などで「移 動中」にも学習している人も $42.1 \%$ 、自宅以外の「学習スペース」などで学習してい る人も $22.3 \%$ ることがわかった。独学者はモバイルテクノロジーやインターネット の進化によって学習方法に変化が生まれ、「旧来の、語学テキストを使用し独力で学 ぶ『独学』や、テレビ、ラジオが媒体となり教室での学習を自宅で再現する形式での 『自宅学習』とは明らかに異なる」（得丸 2019：37）学習形態が一般的になりつつ あり、かつ複数の学習の場で、自分に合った学習形態を選択していることが窥える。

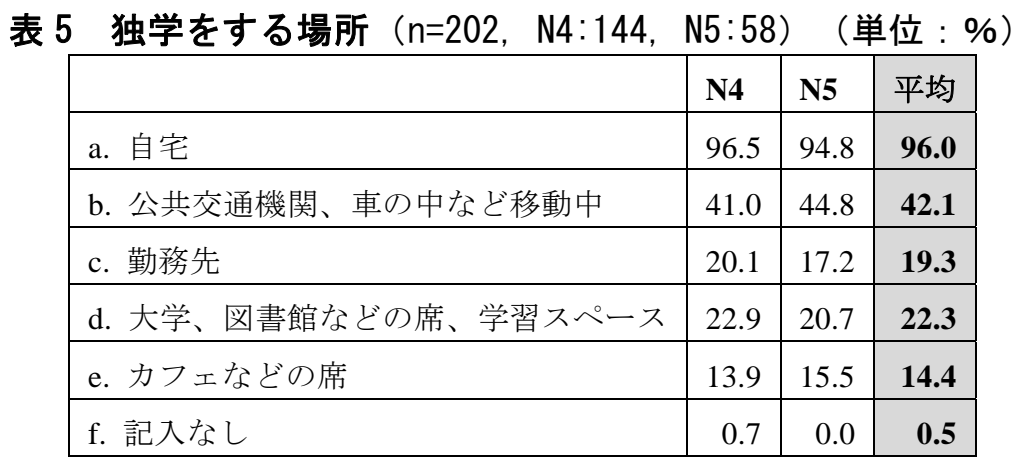

※複数回答可

\section{2 独学者の学習方法、上達実感度}

独学者の学習方法を質問したところ、表 6 の通りとなった。最も多かったのは「市 販の日本語教材 (書籍) での学習」 $(90.1 \%)$ 、次いで「映画、ドラマ、アニメなど を試聴する人」（84.7\%）、「ウェブサイトやYouTube などのコンテンツで自己学習」 (82.7\%)、「日本の歌を聞く」（79.2\%）、「スマホなどのアプリで自己学習」(68.8\%) と続く。この傾向はN4、N5 とも同様である。N4 と N5 で差が大きかったのは「日本 語の新聞、雑誌などを読む」「日本の歌を聴く」と比較的高度な《読み》《聴解力》が 求められる手段、「友人・知人」「SNS」の交流」と生の日本人との交流であること が見て取れる。

\footnotetext{
${ }^{6}$ 本調査では、表 4 の質問項目で $\mathrm{h}$ のみにマークをつけた 202 人の回答を抽出し、集計した。
} 
表 6 独学の方法（ $n=202, N 4: 144, N 5: 58) \quad$ (単位 : \%)

\begin{tabular}{|l|l|l|l|}
\hline & N4 & N5 & 平均 \\
\hline a. 市販の日本語教材 (書籍) で学習 & 92.4 & 84.5 & $\mathbf{9 0 . 1}$ \\
\hline b. 日本語の本、新聞などを読む & 63.2 & 50.0 & $\mathbf{5 9 . 4}$ \\
\hline c. 日本語の漫画を読む & 52.8 & 50.0 & $\mathbf{5 2 . 0}$ \\
\hline d. 映画、ドラマ、アニメなどを視聴 & 84.7 & 84.5 & $\mathbf{8 4 . 7}$ \\
\hline e. 日本の歌を聴く & 82.6 & 70.7 & $\mathbf{7 9 . 2}$ \\
\hline f. 日本語 Podcast、ニュース、ラジオなどを聞く & 55.6 & 50.0 & $\mathbf{5 4 . 0}$ \\
\hline g. ウェブサイトやYouTube などのコンテンツで自己学習 & 81.9 & 84.5 & $\mathbf{8 2 . 7}$ \\
\hline h. スマホなどのアプリで自己学習 & 68.8 & 69.0 & $\mathbf{6 8 . 8}$ \\
\hline i. E ラーニングを受講 & 48.6 & 44.8 & $\mathbf{4 7 . 5}$ \\
\hline j. 友人・知人などとの交流 & 52.8 & 44.8 & $\mathbf{5 0 . 5}$ \\
\hline k. SNS を通じた交流 & 46.5 & 36.2 & $\mathbf{4 3 . 6}$ \\
\hline
\end{tabular}

※複数回答可

\section{3 学習方法別の学習効果}

学習方法別の学習効果を、1～5 の 5 段階で評価してもらったものが表 7 である。 全体的に N4 レベルの学習者群の方が、評価值が高い。「市販教材」「ウェブサイト などのコンテンツ」での学習への評価が 4 を超え、最も高く評価している。次いで 3.5 を超えた項目は「映画、ドラマ、アニメを見る」（3.77）、「スマホでのアプリ 学習」（3.63）となり、市販教材への評価が高いこと、ウェブコンテンツ、視聴覚リ ソースへの評価が高いことが明らかとなった。これら評価の高さと、表 6 で上位の項 目とで相関関係が認められる。

表 7 学習方法別評価（1～5 段階評価の平均値）

\begin{tabular}{|l|l|l|l|}
\hline & $\mathrm{N} 4$ & $\mathrm{~N} 5$ & 全体 \\
\hline a. 市販の日本語教材 (書籍) で学習 & 4.14 & 3.96 & $\mathbf{4 . 0 9}$ \\
\hline b. 日本語の本、新聞などを読む & 3.44 & 2.79 & $\mathbf{3 . 2 8}$ \\
\hline c. 日本語の漫画を読む & 3.11 & 2.69 & $\mathbf{2 . 9 9}$ \\
\hline d. 映画、ドラマ、アニメなどを視聴 & 3.84 & 3.59 & $\mathbf{3 . 7 7}$ \\
\hline e. 日本の歌を聴く & 3.51 & 3.15 & $\mathbf{3 . 4 2}$ \\
\hline f. 日本語 Podcast、ニュース、ラジオなどを聞く & 3.40 & 2.97 & $\mathbf{3 . 2 8}$ \\
\hline g. ウェブサイトやYouTube などのコンテンツで自己学習 & 4.07 & 4.09 & $\mathbf{4 . 0 8}$ \\
\hline h. スマホなどのアプリで自己学習 & 3.64 & 3.63 & $\mathbf{3 . 6 3}$ \\
\hline i. E ラーニングを受講 & 3.11 & 3.23 & $\mathbf{3 . 1 5}$ \\
\hline j. 友人・知人などとの交流 & 3.22 & 3.15 & $\mathbf{3 . 2 1}$ \\
\hline k. SNS を通じた交流 & 3.00 & 2.43 & $\mathbf{2 . 8 6}$ \\
\hline
\end{tabular}


また、図 2 は各項目別に 5 段階の評価を人数で表示したものである。1 あるいは 2 と低評価が多かった項目は「日本語の漫画を読む」「SNS を通じた交流」であった。 回答者の中でこの 2 項目対する効果を低く評価した割合をN4、N5 別に詳しく調べる と、「漫画」は両レベルとも同程度だったのに対して、「SNS」はN5 で低評価を付 けた人の割合が 66.7\%（N4 では 31.3\%）と非常に多いことがわかった。日本語環境で の受容、産出などの総合的な言語能力が求められる SNS での交流は、N5 受験レベル の日本語学習者にとっては高い壁のように感じているのかもしれない。

\section{図 2 学習方法別評価（各項目の詳細）}

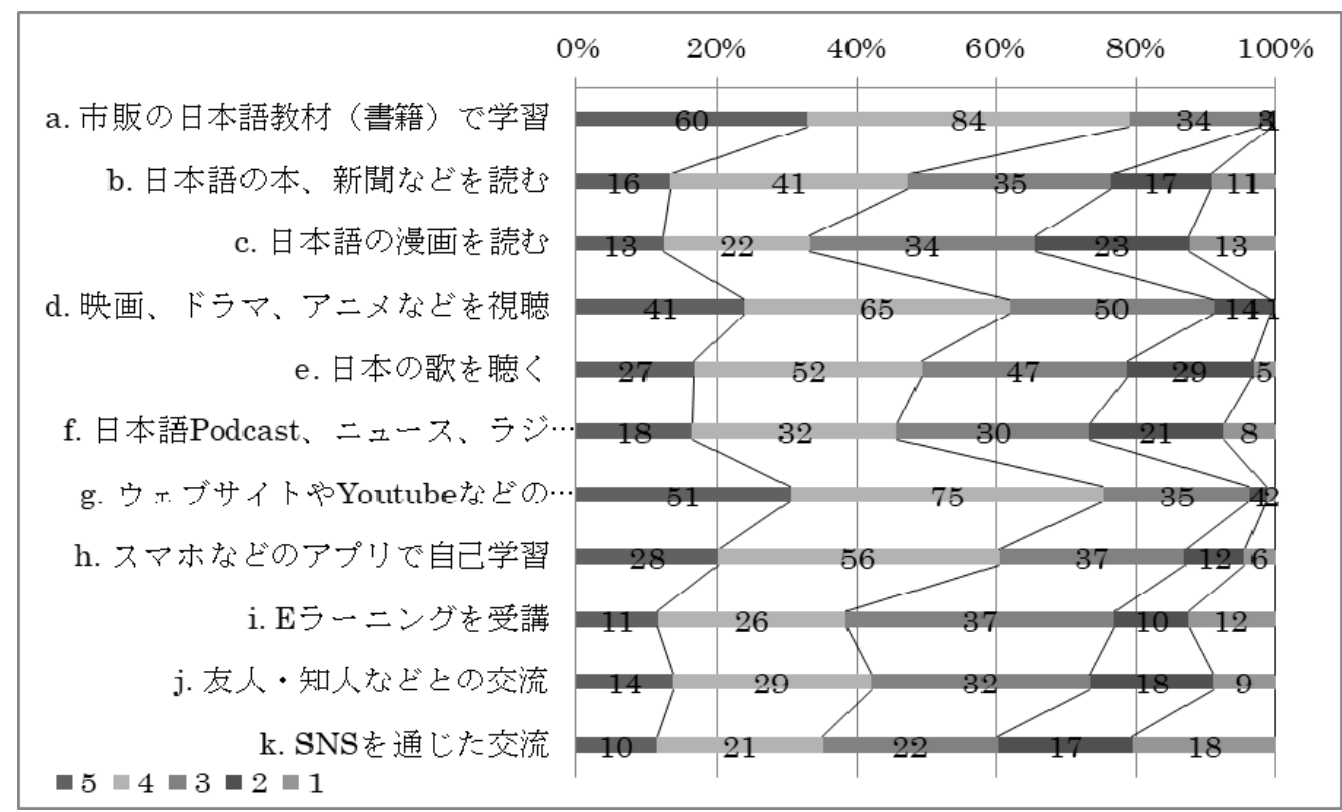

\section{4 独学の利点、効果}

独学の利点、効果について質問したところ、表 8 の通り最も回答の多かったのは「場 所や時間を選ばず学習できる」(76.2\%)、次いで「自分のペースで学習できる」(73.8\%)、 「安く学習できる」（70.8\%）と、自身の学習条件に合致するという回答が挙がった。 この結果は宇田川（2016）の調査結果と合致している。対して、本調査において言語 能力の向上を挙げた割合は高くない。能力別に見ると、「聞く力がついた」が最も多 く 27.2\%、次いで「言語知識（語彙・文法など）が上達した」（25.2\%）、「読む力 がついた」 (23.8\%)」と続き、「書く力」「会話力（やりとり）」「話す力」とい った産出・やり取り能力の向上を実感している割合は相対的に低いことがわかった。 特にN5 群は「聞く力」を除いて N4より低い。 
表 8 独学の利点、効果 $(n=202, N 4: 144, N 5: 58) \quad$ (単位 : \%)

\begin{tabular}{|l|r|r|r|}
\hline \multicolumn{1}{|c|}{} & N4 & \multicolumn{1}{c|}{ N5 } & 平均 \\
\hline a. 楽しく学習できる & 42.4 & 41.4 & $\mathbf{4 2 . 1}$ \\
\hline b. 場所や時間を選ばず学習できる & 78.5 & 70.7 & $\mathbf{7 6 . 2}$ \\
\hline c. 自分のペースで学習できる & 73.6 & 74.1 & $\mathbf{7 3 . 8}$ \\
\hline d. 安く学習できる & 73.6 & 63.8 & $\mathbf{7 0 . 8}$ \\
\hline e. 継続して学習できる & 36.8 & 32.8 & $\mathbf{3 5 . 6}$ \\
\hline f. 趣味の世界が広がった & 38.9 & 19.0 & $\mathbf{3 3 . 2}$ \\
\hline g. 日本語の勉強方法が身についた & 17.4 & 19.0 & $\mathbf{1 7 . 8}$ \\
\hline h. 短期間で上達した & 20.8 & 20.7 & $\mathbf{2 0 . 8}$ \\
\hline i. 日本に関する情報を得られる & 25.7 & 13.8 & $\mathbf{2 2 . 3}$ \\
\hline j. 自分の日本語が相手に通じる & 11.8 & 10.3 & $\mathbf{1 1 . 4}$ \\
\hline k. 聞くカがついた & 27.1 & 27.6 & $\mathbf{2 7 . 2}$ \\
\hline l. 話す力がついた & 11.1 & 10.3 & $\mathbf{1 0 . 9}$ \\
\hline m. 会話力 (やりとり) がついた & 12.5 & 12.1 & $\mathbf{1 2 . 4}$ \\
\hline n. 読む力がついた & 28.5 & 12.1 & $\mathbf{2 3 . 8}$ \\
\hline o. 書く力がついた & 18.1 & 8.6 & $\mathbf{1 5 . 3}$ \\
\hline p. 発音が上達した & 8.3 & 10.3 & $\mathbf{8 . 9}$ \\
\hline q. 言語知識（語彙・文法など）がついた & 29.2 & 15.5 & $\mathbf{2 5 . 2}$ \\
\hline r. 日本語学習の仲間ができた & 8.3 & 8.6 & $\mathbf{8 . 4}$ \\
\hline s. その他 & 0.7 & 0.0 & $\mathbf{0 . 5}$ \\
\hline [「その他」回答] 日本文化を理解する (1 人) & & \\
\hline t. 回答なし & $\mathbf{1 . 0}$ \\
\hline
\end{tabular}

※複数回答可

一方、調査対象者のうち、日本語教育機関に通う 398 人には、クラス学習の効果を 質問した。表 9 の通り、最も多かった回答は「継続して学習できる」であった。また、

「言語知識（語彙・文法など）がついた」「話す力がついた」「読む力がついた」「聞 く力がついた」「話す力がついた」「発音が上達した」といった言語能力に関する効 果を感じていることが読夕取れ、表 8 の独学者の回答とは対照的となった。また、「日 本語の勉強方法が身についた」「楽しく学習できる」と回答した割合も、独学者と比 ベ高かった。 
表 9 クラス学習の効果（ $\mathrm{n}=398, \quad \mathrm{~N} 4: 237, \quad \mathrm{~N} 5: 161) \quad$ (単位 : \%)

\begin{tabular}{|l|l|l|r|}
\hline & $\mathrm{N} 4$ & $\mathrm{~N} 5$ & 平均 \\
\hline a. 楽しく学習できる & 45.1 & 41.6 & $\mathbf{4 3 . 7}$ \\
\hline b. クラスメイトから刺激や学びを得られる & 32.5 & 27.3 & $\mathbf{3 0 . 4}$ \\
\hline c. 趣味の世界が広がった & 29.5 & 28.6 & $\mathbf{2 9 . 1}$ \\
\hline d. 日本語の勉強方法が身についた & 50.6 & 55.3 & $\mathbf{5 2 . 5}$ \\
\hline e. 継続して学習できる & 64.1 & 53.4 & $\mathbf{5 9 . 8}$ \\
\hline f. 自分の日本語が相手に通じる & 38.4 & 41.0 & $\mathbf{3 9 . 4}$ \\
\hline g. 日本に関する情報を得られる & 29.5 & 29.8 & $\mathbf{2 9 . 6}$ \\
\hline h. 聞く力がついた & 46.8 & 54.7 & $\mathbf{5 0 . 0}$ \\
\hline i. 話す力がついた & 51.1 & 62.1 & $\mathbf{5 5 . 5}$ \\
\hline j. 会話力 (やりとり) がついた & 44.3 & 52.8 & $\mathbf{4 7 . 7}$ \\
\hline k. 読む力がついた & 49.8 & 57.8 & $\mathbf{5 3 . 0}$ \\
\hline l. 書く力がついた & 46.8 & 54.0 & $\mathbf{4 9 . 7}$ \\
\hline m. 発音が上達した & 42.6 & 45.3 & $\mathbf{4 3 . 7}$ \\
\hline n. 言語知識（語彙・文法など）がついた & 59.5 & 51.6 & $\mathbf{5 6 . 3}$ \\
\hline o. その他 & 0.8 & 0.6 & $\mathbf{0 . 8}$ \\
\hline p. 回答なし & 2.0 & 0.0 & $\mathbf{1 . 3}$ \\
\hline
\end{tabular}

※複数回答可

\section{5 独学の欠点、課題}

独学者に独学の欠点、課題と感じることを質問したところ、表 10 の通りとなった。 最も多かったのは「自分の日本語が相手に通じるのかわからない」（65.8\%）だった。 次いで「効果的な勉強方法がわからない」（44.6\%）、「学習計画を立てられない」 (23.3\%) と続き、独学者が学習方法、自律学習の確立に悩んでいる実態が明らかと なった。

表 10 独学の欠点、課題（ $n=202, \quad N 4: 144, \quad N 5: 58 ）$ (単位：\%）

\begin{tabular}{|l|r|r|r|}
\hline & \multicolumn{1}{|c|}{ N4 } & \multicolumn{1}{|c|}{ N5 } & \multicolumn{1}{|c|}{ 平均 } \\
\hline a. 学習が楽しくない & 2.8 & 1.7 & 2.5 \\
\hline b. 孤独を感じる & 22.7 & 20.7 & $\mathbf{2 1 . 8}$ \\
\hline c. 学習が続かない & 13.5 & 25.9 & $\mathbf{1 6 . 8}$ \\
\hline d. 上達の実感が得られない & 18.4 & 15.5 & $\mathbf{1 7 . 3}$ \\
\hline e. 目標が見つからない & 19.9 & 13.8 & $\mathbf{1 7 . 8}$ \\
\hline f. 学習計画を立てられない & 24.1 & 22.4 & $\mathbf{2 3 . 3}$ \\
\hline g. 効果的な勉強方法がわからない & 45.4 & 44.8 & $\mathbf{4 4 . 6}$ \\
\hline h. 自分の日本語が相手に通じるのかわからない & 69.6 & 60.3 & $\mathbf{6 5 . 8}$ \\
\hline
\end{tabular}




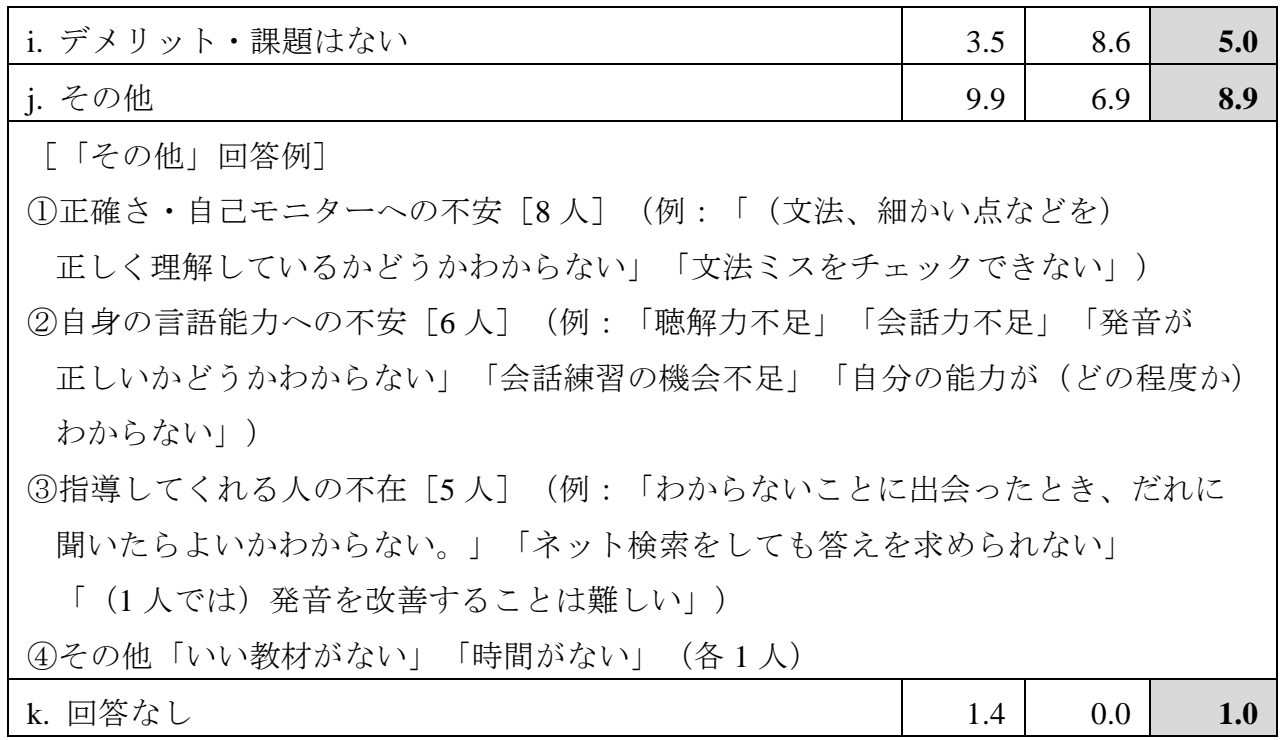

※複数回答可

\section{6 独学者の日本語学習歴、教育機関に対する意識}

図 3 は、独学者に過去に教育機関で学習経験があるかどうかを質問した結果である。 61\%が「経験あり」と回答した。表 11 は、「あり」との回答者に、教育機関を辞め た理由を質問した回答の集計である。最も多かったのは「通う時間がなくなったから」 というもので、「生活、人生で大きな変化が起きたから」など自身や周辺の社会環境 の変化が大きな要因であることは、瀬尾他（2012）の調査でも指摘されていることで ある。また、「当初の目標を達成した」（17.1\%）という積極的な動機もあれば、「コース が自分に合わなかった」（16.3\%）「一定のレベルまでしかクラス設定がなかった」 といったコースの条件要因、「なかなか上達しなかった」（4.1\%）など能力の理由も 挙げられており、「その他」の自由記述にも多種の理由が挙げられている。

図 3 過去に教育機関で日本語を学習していた独学者の割合 $(n=202, N 4: 144, N 5: 58)$

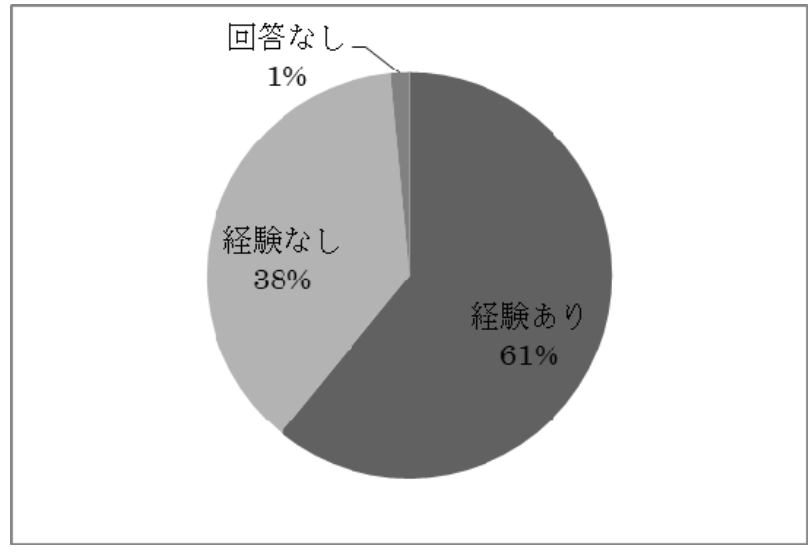




\section{表 11 学習機関を辞めた理由（ $n=123, \quad N 4: 90, \quad N 5: 33)$ （単位：\%）}

\begin{tabular}{|c|c|c|c|}
\hline & N4 & N5 & 平均 \\
\hline a. 他に熱中したいものが見つかったから & 3.3 & 0.0 & 2.4 \\
\hline b. 通う時間がなくなったから & 54.4 & 66.7 & 57.7 \\
\hline c. 当初の目標を達成したから & 16.7 & 18.2 & 17.1 \\
\hline d. 目標が見つからなかったから & 1.1 & 9.1 & 3.3 \\
\hline e. コースが自分に合わなかつたから & 15.6 & 18.2 & 16.3 \\
\hline f. なかなか上達しなかったから & 2.2 & 9.1 & 4.1 \\
\hline g. 生活、人生で大きな変化が起きたから & 14.4 & 9.1 & 13.0 \\
\hline h. 学んでも使う場がないから & 5.6 & 9.1 & 6.5 \\
\hline i. その他 & 23.3 & 12.1 & 20.3 \\
\hline \multicolumn{4}{|c|}{$\begin{array}{l}\text { [「その他」回答例 }] \\
\text { 一定のレベルまで（例：入門・初級クラス、N4 レベル、大学のクラス等） } \\
\text { しかクラス設定がなかった。（9人）／授業料が高い（5人）／進度が遅い } \\
\text { （3八）／日常会話にフォーカスした方が面白い（以下、1人） } \\
\text { ／マイペースを守りたい／先生が休んだ／（コースに）終わりがない／市販 } \\
\text { 教材が多いため、独習できる／独習する方が自分の目標に達することができる } \\
\text { ／幼い頃に日本語に触れたことがある }\end{array}$} \\
\hline j. 記入なし & 2.2 & 0.0 & 1.6 \\
\hline
\end{tabular}

※複数回答可

一方、日本語教育機関で学習している協力者に、「現在の機関を選んだ理由」を 質問したところ、表 12 の通り、「長く学習するため」（47.7\%）が最も多く、次い で「日本語の勉強方法を身につけるため」（41.2\%）「仲間と一緒に勉強する方が いい」（33.9\%）とクラス学習の利点を感じていることが窅える。「コース内容が 自分の希望に合っている」（29.4\%）「通うのに便利な場所」（29.1\%）「教師・授業 の質がいい」（27.9\%）などの機関の特色も上位に挙がった。独学の課題に「効果的 な勉強方法がわからない」との意見が多かったが、それと呼応する結果となった。学 習者が独学、通学の選択において、自分の求める学習条件を吟味している様子が見て 取れる。 
表 12 現在通っている日本語教育機関を選んだ理由（ $\mathrm{n}=398, N 4: 237, N 5: 161)$ （単位 : \%)

\begin{tabular}{|c|c|c|c|}
\hline & N4 & N5 & 平均 \\
\hline a. 教師・授業の質がいいから & 27.8 & 28.0 & 27.9 \\
\hline b. コース内容が自分の希望に合っているから & 26.6 & 33.5 & 29.4 \\
\hline c. 通うのに便利な場所だから & 30.8 & 26.7 & 29.1 \\
\hline d. 日本語の勉強方法を身につけるため & 41.8 & 40.4 & 41.2 \\
\hline e. 長く学習するため & 51.9 & 41.6 & 47.7 \\
\hline f. 学費が安いから & 26.2 & 19.9 & 23.6 \\
\hline g. 独学、個人教授より、仲間と一緒に勉強する方がいいから & 38.8 & 26.7 & 33.9 \\
\hline h. 留学の機会があるから & 5.1 & 4.3 & 4.8 \\
\hline i. 就職や仕事のキャリアアップにつながるから & 8.0 & 5.0 & 6.8 \\
\hline j. 学校のブランド（名前、伝統など） & 12.2 & 18.0 & 14.6 \\
\hline k. 家族・友達などに勧められたから & 20.3 & 18.6 & 19.6 \\
\hline l. その他 & 4.2 & 7.5 & 5.5 \\
\hline \multicolumn{4}{|c|}{$\begin{array}{l}\text { [「その他」回答例 }] \\
\mathrm{CEF}^{7} \text { に申請できるから（6 人）／趣味・旅行（5 人）／広告を見て（以下、1人） } \\
\text { ／集中コースがある／無料だから／たまに書き取りがあり、学習意欲が高まる／ } \\
\text { (日本語は）割合簡単／移民／先生が皆日本人／先生との相性／異性と出会うため }\end{array}$} \\
\hline m. 回答なし & 0.4 & 0.6 & 0.5 \\
\hline
\end{tabular}

\section{5. まとめ}

本調査で明らかになったことでは、独学者は自分のペースで学習できるメリットを 強く感じている一方、勉強方法への不安、自身の日本語力が通じるかどうかを確認 する機会がないことに課題を感じており、言語能力の向上については、クラス学習者 ほどは実感していないことが明らかになった。ただし 4.5 の通り、「上達の実感がない」 ことを課題に感じている人の割合は 2 割以下だったことから、必ずしも言語能力の 向上を一義的な目的と設定していない独学者が多いのではないかと推測できる。

また、独学の学習方法については、本などの教材を用いた従来の方法、ウェブコン テンツ、また映画・ドラマなど主に聴解のインプットから学習する方法への評価が 高い一方、話す・書く能力の向上の実感度は低いことがわかった。

7 香港政府による生涯学習への助成プログラム「The Continuing Education Fund (持讀進修基金)」。 条件を満たせば年 HKD20,000（2019 年現在）を上限に還付される。 
本調査は、実施機会が初級学習者に協力を依頼できる場に限られているのだが、 今後機会があれば中級以上の学習者への量的調查も実施したいと考えている。

今後の研究課題としては、独学者の日本語接触場面、日本語使用コミュニティとの 関わり方や相互理解などを明らかにすることである。宇田川（2016）は、インター ネットを活用してのネットワーク形成、地域コミュニティでの交流を提言しているが、 中級以上の学習者には効果的と言えるが、表 7 からわかった通り、本調查の対象者で ある初級独習者にとって日本語使用者との交流はいささか難しい部類の学習方法な のかもしれない。現実世界、SNS いずれのコミュニティであっても、初級者が気軽に 参加できるような配慮が必要ではないだろうか。今後日本語環境コミュニティとの 関わり方について調查する必要があると考える。 


\section{参考文献}

宇田川洋子・李夢娟・李澤森・劉礪志（2014）「香港の日本語学習者減少の要因－調查報告－」

『日本學刊』第17号, 107-120

宇田川洋子・梁安玉・李澤森・李夢娟（2016）「独学で日本語を学ぶ人の学習意識と学習スタイル」

『第 10 回国際日本語教育・日本研究シンポジウム大会論文集』香港日本語教育研究会, 141-155 木山登茂子・中野貴子・周宏陽・上田早苗・望月貴子・蘇凱達・青山玲二郎（2011）「2010年香港

日本語学習者背景調査報告」『日本學刊』第14号, 176-195

許淑君（2020）「2019 年度香港・マカオ日本語能力試験実施報告」『日本學刊』第 23 号, 121-134 久保田竜子 - 瀬尾匡輝 - 鬼頭夕佳・佐野香織・山口悠希子・米本和弘（2014）「余暇活動と消費と

しての日本語学習」『第 9 回国際日本語教育・日本研究シンポジウム大会論文集 日本語教育と

日本研究における双方向性アプローチの実践と可能性』ココ出版, 69-85

国際交流基金（2015）『2015 年度日本語教育機関調査』（2020 年 1 月 24 日最終閲覧）

https://www.jpf.go.jp/j/project/japanese/survey/result/dl/survey_2015/all.pdf

国際交流基金・電通（2016）『台湾・香港・韓国 日本語学習者調查結果』（2020年 1 月 24 日最終

閲覧）https://drive.google.com/file/d/0B_YYwiD__l6lblRNVElULUpwS28/view

斎藤誠・梁安玉 ・劉獂志・李澤森・李夢娟（2019）「2018年香港の日本語学習者背景調査」『日本

學刊』第22号, 114-127

瀬尾匡輝・山口悠希子（2014）「インフォーマル・ラーニング下における日本語学習」『第 9 回

国際日本語教育・日本研究シンポジウム大会論文集 日本語教育と日本研究における双方向性 アプローチの実践と可能性』ココ出版, 89-99

瀬尾匡輝・陳徳奇・司徒棟威（2012）「なぜ日本語学習をやめてしまったのか一香港の社会人教育

機関における動機減退要因の一事例一」『日本學刊』第 15 号, 80-99

得丸智子（2019）「日本語独学者の研究」『開智国際大学紀要』第 18 号, 37-56

山下直子・梁安玉・劉礪志・李澤森・侯清儀・李夢娟（2016）「2015年香港日本語学習者背景調査」

『日本學刊』第19号, 185-197

劉礪志（2012）「2011 年度香港・マカオ日本語能力試験実施報告」『日本學刊』第 15 号, 136-148 劉嘱志（2013）「2012 年度香港・マカオ日本語能力試験実施報告」『日本學刊』第 16 号, 247-261

劉礪志（2014）「2013 年度香港・マカオ日本語能力試験実施報告」『日本學刊』第 17 号, 121-132

劉礪志（2015）「2014 年度香港・マカオ日本語能力試験実施報告」『日本學刊』第 18 号, 134-144

劉䃇志（2016）「2015 年度香港・マカオ日本語能力試験実施報告」『日本學刊』第 19 号, 198-211

劉礪志（2017）「2016 年度香港・マカオ日本語能力試験実施報告」『日本學刊』第 20 号, 103-116

劉礪志（2018）「2017 年度香港・マカオ日本語能力試験実施報告」『日本學刊』第 21 号, 193-207

劉䃇志（2019）「2018 年度香港・マカオ日本語能力試験実施報告」『日本學刊』第 22 号, 128-141 